\title{
SOME PROPERTIES OF ZIPF-MANDELBROT LAW AND HURWITZ $\zeta$-FUNCTION
}

\author{
JuliJe JAKŠETIĆ, Đilda PeČARIĆ AND Josip PeČARIĆ
}

\begin{abstract}
In this paper we deal with analytical properties of the Zipf-Mandelbrot law. If total mass of this law is spread all over positive integers we come to Hurwitz $\zeta$-function. As we show, it is very natural first to examine properties of Hurwitz $\zeta$-function to derive properties of Zipf-Mandelbrot law. Using some well-known inequalities such as Chebyshev's and Lyapunov's inequality we are able to deduce a whole variety of theoretical characterizations that include, among others, log-convexity, log-subadditivity, exponential convexity.
\end{abstract}

Mathematics subject classification (2010): Primary 26D15, Secondary 26D20.

Keywords and phrases: Zipf-Mandelbrot law, Hurwitz $\zeta$-function, log-convexity, Chebyshev's inequality, Lyapunov's inequality.

\section{REFERENCES}

[1] G. BAstien, M. Rogalski, Convexité, complète monotonie et inégalités sur les fonctions zêta et gamma, sur les fonctions de opérateurs de Baskakov et sur les fonctions arithmétiques, Can. J. Math. 54, 5 (2002), 916-944.

[2] S. Frontier, Diversity and structure in aquatic ecosystems, Mar. Biol. Ann. Rev. 23 (1985), $253-$ 312.

[3] L. Horváth, Đ. PeČarić, J. PeČarić, Estimations of $f$ and Rényi divergences by using a cyclic refinement of the Jensen's inequality, Bull. Malays. Math. Sci. Soc. (accepted).

[4] J. JAKŠEtiĆ, J. PeČARIĆ, Exponential Convexity method, J. Convex Anal. 20, 1 (2013), 181-197.

[5] A. LELU, Jean-Baptiste Estoup and the origins of Zipf's law: a stenographer with a scientific mind (1868-1950), Boletiín de Estadiística e Invenstigación Operativa 6-77, 30, 1 (2014), 66-77.

[6] B. Mandelbrot, An information theory of the statistical structure of language, In Jackson, W., editor, Communication Theory, New York, Academic Press, 1953.

[7] D. Y. Manin, Mandelbrot's Model for Zipf's Law: Can Mandelbrot's Model Explain Zipf's Law for Language?, 16, 3 (2009), 274-285.

[8] D. Mouillot, A. Lepretre, Introduction of relative abundance distribution (RAD) indices, estimated from the rank-frequency diagrams (RFD), to assess changes in community diversity, Environmental Monitoring and Assessment 63, 2 (2000), 279-295.

[9] J. PEČARIĆ, Nejednakosti, Hrvatsko matematičko društvo, Zagreb, 1996.

[10] J. PeČArić, F. Proshan, Y. L. Tong, Convex functions partial ordering and statistical applications mathematics in Science and Engineering, vol. 187., Academic Press, 1992.

[11] J. B. WiLson, Methods for fitting dominance/diversity curves, 2 (1991), 35-46.

[12] G. K. ZIPF, Human Behavior and the Principle of Least Effort, Addison-Wesley, Reading, MA, 1949. 